\title{
Egg quality and sensory evaluation as affected by temperature and storage days of fertile and non-fertile eggs
}

${ }^{1}$ Nwamo, A. C., ${ }^{2}$ Oshibanjo, D. O., ${ }^{1}$ Sati, N. M, ${ }^{1}$ Emennaa, P. E., ${ }^{1}$ Mbuka, J. J., ${ }^{1}$ Njam R. L., ${ }^{1}$ Bature, E., ${ }^{1}$ Ejidare, D. A., ${ }^{1}$ Gyang, B. D., ${ }^{2}$ Adeniyi, A. K, ${ }^{2}$ Mohammed, M. Y., ${ }^{2}$ Luka J. Agwom and ${ }^{2}$ Ene, P. N.

${ }^{*}$ Poultry Division National Veterinary Research Institute, Vom, Jos Plateau State Nigeria

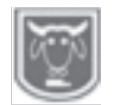

${ }^{2}$ Department of Animal Production, University of Jos, Jos Plateau State Nigeria Abstract Corresponding author:akuchi.nwamo@yahoo.com; +2348035739034

Internal and external qualities of eggs deteriorate with time. This process of deterioration cannot be stopped but the rate at which it occurs can be reduced. The aim of this study is to evaluate the main effect of temperature and storage duration on the egg quality characteristics and sensory evaluation of fertile and non-fertile eggs. A total of 600 fertile and non-fertile eggs were obtained from Lohmann Brown hen, at 44 weeks of age. Roosters were removed from the hen that laid non-fertile eggs. Eggs collection started after 30 days of roaster withdrawal. Out of the 300 eggs in each of the storage methods, eggs at storage days 5, 10, 15 and 20, respectively were randomly picked for determination of egg quality characteristics and sensory evaluation in $2 \times 2$ Factorial arrangement in a completely randomized design. The storage methods were room temperature (ambient) and refrigeration $\left(10^{\circ} \mathrm{C}\right)$. External and internal quality characteristics of eggs were taken, and sensory evaluations was taken from both fertile and non-fertile eggs. Data were analysed using descriptive statistic and ANOVA at $\alpha_{0.05}$. There was significant difference $(p<0.05)$ between fertile and non-fertile eggs external and internal characteristics. Both the fertile and nonfertile eggs weight under the refrigerator had the highest values while both the fertile and non-fertile eggs weight under the room temperature had the lower egg weight values. Significant difference $(p>0.05)$ existed among all yolk parameters measured except yolk colour. Yolk weight, height and index were significantly higher in fertile egg stored in the refrigerator while fertile egg stored in the refrigerator has the lowest yolk weight and ratio. There was significant difference $(p<0.05)$ that existed in albumen weight, albumen height, albumen ratio and albumen index for fertile and non-fertile. The albumen height was higher in fertile eggs stored at refrigerator temperature while non-fertile eggs stored at room temperature had the least height. Non-fertile eggs stored at room temperature and refrigerator temperature had the highest albumen length $108.88 \mathrm{~cm}$ and $100.80 \mathrm{~cm}$ respectively with least length in fertile eggs stored at the refrigerator. The Haugh unit of fertile egg stored in refrigerator is significantly higher $(p<0.05)$. There was no significant difference $(p>0.05)$ that existed for odour, aroma, taste, texture and overall acceptability for all the treatments. The egg weight was significantly $(p<0.05)$ higher at storage day 10, than all the storage days. The yolk weight for storage day 10 was significantly $(p<0.05)$ higher than all the storage days. The yolk diameter for storage days 5, 10 and 15 were statistically similar ( $p>0.05)$. The yolk colour was significantly $(p<0.05)$ higher on storage day 15 and lower on day 0. The albumen heights decreased significantly $(p<0.05)$ as the days of storage increased. The albumen length at storage day 20 was significantly $(p<0.05)$ higher than all the storage days. The Haugh unit decrease significantly $(p<0.05)$ during the period of storage. In conclusion, fertile eggs can be stored in refrigerator for 10 days without adverse effect on egg qualities.

Keywords: Storage temperature and storage duration, fertile egg, non-fertile egg and egg quality characteristics 
Egg quality and sensory evaluation as affected by temperature and storage

\section{La qualité des œufs et l'évaluation sensorielle affectées par la température et les jours de stockage des oufs fertiles et non fertiles}

\section{Résumé}

Les qualités internes et externes des oufs se détériorent avec le temps. Ce processus de détérioration ne peut pas être arrêté, mais la vitesse à laquelle il se produit peut être réduite. L'objectif de cette étude est d'évaluer l'effet principal de la température et de la durée de stockage sur les caractéristiques de qualité des oufs et l'évaluation sensorielle des æufs fertiles et non fertiles. Au total, 600 oufs fertiles et non fertiles ont été obtenus auprès de la poule Lohmann Brown, à l'âge de 44 semaines. Les coqs ont été retirés de la poule qui pondait des oufs non fertiles. La collecte des oufs a commencé après 30 jours de retrait de la rôtissoire. Sur les 300 oeufs de chacune des méthodes d'entreposage, les aufs aux jours d'entreposage 5, 10, 15 et 20, respectivement, ont été choisis au hasard pour déterminer les caractéristiques de qualité des oufs et l'évaluation sensorielle dans un arrangement factorial $2 \times 2$ dans une conception complètement randomisée. Les méthodes de stockage étaient la température ambiante (ambiante) et la réfrigération (100C). Des caractéristiques externes et internes de qualité des oeufs ont été prises, et des évaluations sensorielles ont été prises des oeufs fertiles et non fertiles. Les données ont été analysées à l'aide de statistiques descriptives et d'ANOVA à $\alpha 0,05$. Il y avait une différence significative $(p<0,05)$ entre les oufs fertiles et non fertiles caractéristiques externes et internes. Le poids des aufs fertiles et non fertiles sous le réfrigérateur avait les valeurs les plus élevées, tandis que le poids des oufs fertiles et non fertiles sous la température ambiante avait les valeurs inférieures du poids des oufs. La différence significative $(p>0,05)$ existait entre tous les paramètres jaunes mesurés à l'exception de la couleur du jaune. Le poids, la taille et l'indice du jaune étaient significativement plus élevés dans les oufs fertiles conservés au réfrigérateur, tandis que les œufs fertiles conservés au réfrigérateur avaient le poids et le rapport jaunes les plus bas. Il y avait une différence significative $(p<0,05)$ qui existait dans le poids de l'albumen, hauteur de l'albumen, rapport albumen et indice albumen pour fertile et non fertile. La hauteur de l'albumen était plus élevée dans les oufs fertiles stockés à la température du réfrigérateur, tandis que les aufs non fertiles stockés à température ambiante avaient le moins de hauteur. Les oufs non fertiles stockés à température ambiante et la température du réfrigérateur avaient la longueur d'albumen la plus élevée $108,88 \mathrm{~cm}$ et 100,80 cm respectivement avec moins de longueur dans les aufs fertiles conservés au réfrigérateur. L'unité Haugh d'œufs fertiles entreposés au réfrigérateur est significativement plus élevée $(p<0,05)$. Il n'y avait aucune différence significative $(p>0,05)$ qui existait pour l'odeur, l'arôme, le goût, la texture et l'acceptabilité globale pour tous les traitements. Le poids des æufs était significativement $(p<0,05)$ plus élevé au jour 10 de stockage que tous les jours d'entreposage. Le poids du jaune pour le jour 10 de stockage était significativement $(p<0,05)$ plus élevé que tous les jours d'entreposage. Le diamètre du jaune pour les jours d'entreposage 5, 10 et 15 était statistiquement semblable $(p>0,05)$. La couleur jaune était significativement $(p<0,05)$ plus élevée le jour de stockage 15 et inférieure le jour 0 . Les hauteurs des albums ont considérablement diminué $(p<0,05)$ à mesure que les jours de stockage augmentaient. La longueur de l'album au jour de stockage 20 était significativement $(p<0,05)$ plus élevée que tous les jours de stockage. L'unité Haugh diminue considérablement $(p<0,05)$ pendant la période d'entreposage. En conclusion, les oufs fertiles peuvent être conservés au réfrigérateur pendant 10 jours sans effet négatif sur les qualités des œufs.

Mots-clés: Température de stockage et durée de stockage, œuf fertile, caractéristiques non fertiles de la qualité des œufs et des œufs 


\section{Introduction}

Eggs are excellent sources of high quality protein and are also good sources of iron, vitamin (except vitamin $\mathrm{C}$ ) and phosphorus but are low in calcium. Egg protein is usually referred to as "HBV" protein, meaning protein with High Biological Value. Eggs consist of a complete range of amino acids including branch chain amino acids (methionine and cysteine), lysine, tryptophane and other essential amino acids thus earning the title- " Complete Protein"(George, 2015). Eggs are good sources of vitamins B1, B2,B3, B5, B6,B12, choline, Biotin, Folic acid and also contains selenium and iodine making eggs an excellent food for infants, children, adolescents, convalescents and older people (FAO, 2003)Raw egg white contains a glycoprotein called avidin which binds with biotin to form an avidin-biotic complex which cannot be absorbed by the human digestive tract, however, cooking denatures avidin glycoprotein making it unable to bind with biotin (George, 2015). Internal and external qualities of eggs deteriorate with time. This process of deterioration cannot be stopped but the rate at which it occurs can be reduced (Kristy, 2011). These changes occur as a result of biological and physico-chemical occurrences mainly due to proteolysis and movement of bacteria into egg shell under poor storage conditions (Obi and Igbokwe, 2009). Freshly laid eggs contain few organisms capable of causing spoilage but washing of eggs or storing of eggs in damp conditions cause bacteria to penetrate and multiply causing green, black, and red rots and mold spores on egg to germinate, grow and penetrate the egg shell (FAO, 2003). Condensation following removal of eggs from refrigerated storage into ambient temperature also provides favorable conditions for the penetration of bacteria (FAO, 2003). The main degradation factors for eggs are storage days (time), (Bell
1996), temperature, humidity, air movement, and handling (Stadelman 1995; Samli et al., 2005). Internal quality deterioration of eggs can be retarded significantly by maintaining storage temperature, because quality deterioration occurs faster at high temperatures than at refrigerated temperatures during storage (Zeidler, 2002; Joseph and Ogudele 1996). Egg storage influences the rate at which eggs undergo physical and biochemical changes that lead to the reduction in egg quality thus influencing its nutritional composition and acceptability for consumption and other uses (Fasina, 2012; Mohammed, 2011; Okeudo et al, 2005; Raji, 2009; Scotts \& Silversides, 2000). According to Stadelman (1986), egg quality refers to the characteristics of an egg that will affect its acceptability to the consumer. It then becomes necessary to properly store eggs in order to maintain its quality and also to derive maximum utility from utilization of eggs.

Therefore, this study aims at identifying a suitable method that will significantly reduce the rate at which biological and physiochemical changes occur within the egg with respect to storage and temperature.

\section{Materials and methods \\ Experimental site}

This experiment was conductedin the Animal Products and Processing laboratory, Department of Animal Production, University of Jos, Jos-North Local Government Area (LGA) of Plateau State. It is situated at the extreme North of the State and located between latitude $9^{\circ}$ E55' North of the Greenwich meridian and longitude $8^{0}$ E54' East of the Equator (Haruna et al., 2007).

\section{Collection of experimental material}

A total of 600 fertile and non-fertile eggs was collected from Poultry Division of National Veterinary Research Institute, Plateau State (NVRI) in four successive 
weeks were used for this study. Eggs were obtained from Lohmann brown hen, at 44 weeks of age to evaluate egg quality characteristics. Roosters were removed from the hen that laid non-fertile eggs. Eggs collection started after 30 days of rooster withdrawal. Out of the 300 eggs in each of the storage methods, 20 were picked at random after the following storage days $(5$, 10,15 and 20 respectively) for determination of egg quality characteristics and the remaining eggs were used at every storage day for sensory evaluation. The storage methods were room temperature (ambient) and refrigeration.

\section{Sampling procedure}

Sampling and storing of egg

Immediately after egg collection, eggs were labeled and numbered using a non-harmful permanent marker. Eggs were weighed according to date of collection by using sensitive scale. To study the effect of storage days on egg quality parameters, eggs were stored in refrigerator at $10^{\circ} \mathrm{C}$, ambient (room) temperature of $28-31{ }^{\circ} \mathrm{C}$ for $5,10,15$ and 20 days, and humidity was 55 to $60 \%$ for all treatments. The stored eggs were identified and analyzed at each corresponding storage days and temperature.

\section{Evaluation of egg quality}

External quality characteristics of eggs were taken, which are egg length and egg width $(\mathrm{cm})$, were measured with a digital Vernier caliper, egg weight was measured by weighing egg individually using a sensitive scale, and its shell weight was taken as the weight of the oven dried egg shell. The shell thickness which is the thickness of the dried egg shell was measured with a micrometer screw gauge (the mean of the three points- narrow, broad and middle was taken as the shell thickness). After this process, eggs were carefully cracked with a spoon in a flat plate on a table without breaking the vitelline membrane, in order to measure the internal quality characteristics. The parameters were then taken immediately. The internal parameters measured were:

Yolk Width: Measured as the widest horizontal circumference with a Vernier caliper.

Yolk Height: Measured as the height of the yolk at mid-point with a tripod micrometer.

Albumen Height: Measured as the height of the thick albumen.

Albumen Width: Measured as the widest horizontal circumference and,

Albumen Weight: Calculated as the difference in weight of the egg and weight of the yolk plus shell.

Yolk Index: Was calculated as the yolk height divided by the yolk width $(\mathrm{cm})$.

Albumen Index: Is the ratio of the albumen height to egg width.

Haugh unit was determined using the formula below:

$\mathrm{HU}=100 \log \left(\mathrm{H}+7.5-1.7 \mathrm{~W}^{\wedge} 0.35\right.$

Where $\mathrm{HU}=$ Haugh unit

$\mathrm{H}=$ Height of the thick albumen (mm)

$$
\mathrm{W}=\text { Egg weight (grams) }
$$

\section{Sensory evaluation}

At every storage day, eggs from each treatment were sampled for sensory evaluation. Samples for sensory evaluations was taken from both fertile and non-fertile eggs, total of 20 trained individuals aged between 22-35 years' males and females from department of Animal Production University of Jos, Plateau State were employed to assess the coded egg samples. Equal bite size from each treatment was coded, replicated thrice and served for evaluation by the trainees on a 9-point hedonic scale for colour, aroma, odour, taste, texture and overall acceptability. The eggs were cooked by bringing tap water to boil at $100^{\circ} \mathrm{C}$ and simmer for 20 minutes. Eggs were shelled and presented to the trained 20-man panelist who judged using a nine-point hedonic scale from 9 (extremely like) to 1 (extremely dislike). Cold distilled water 
was provided for panelists to rinse their mouth in between samples.

\section{Experimental design}

A $2 \times 2 \times 5$ factorial arrangement in a Completely Randomized Design was used for this study.

2 storage temperature, 2 egg types (Fertile and non-fertile eggs) and 5 storage duration.

\section{Statistical analysis}

Data collected were analyzed using General linear model of SAS (SAS 2010). Statistical variations were observed and means were separated using Duncan's multiple range test.

\section{Results}

Main effect of temperature difference on fertile and non-fertile egg external and external characteristics

The main effect of temperature difference on fertile and non-fertile egg external and internal characteristics is shown in Table 1. There was significant difference $(p<0.05)$ between fertile and non-fertile eggs external and internal characteristics. The fertile and non-fertile eggs stored under the refrigerator had the highest egg weight while the fertile and non-fertile eggs storage under the room temperature had the lowest egg weight. No significant difference ( $>0.05)$ was observed in the egg length and egg width of fertile and non-fertile eggs the during the storage method. However, the egg width of non-fertile egg stored in refrigerator was recorded to be the highest. Significant difference $(p>0.05)$ existed among all parameters measured except yolk colour. Yolk weight, height and index were significantly higher in fertile egg stored in the refrigerator while fertile egg stored in the refrigerator has the lowest yolk weight and ratio. There was significant difference $(p<0.05)$ that existed in albumen weight, albumen height, albumen ratio and albumen index for fertile and non-fertile. Albumen weight was higher in non-fertile egg stored at refrigerator temperature with least albumen weight in fertile egg stored at room temperature. The albumen height was higher in fertile eggs stored at refrigerator temperature while non- fertile eggs stored at room temperature had the least height. Nonfertile eggs stored at room temperature and refrigerator temperature had the higher albumen length $108.88 \mathrm{~cm}$ and $100.80 \mathrm{~cm}$, respectively with least length in fertile eggs stored at the refrigerator. Albumen ratio was higher in non-fertile stores under refrigerator while the least value is obtained under room temperature. Non-fertile eggs stored under refrigerator had the highest albumen index with least value in eggs stored under room temperature. The yolk: albumen, haugh unit and egg surface area shows significant difference $(p<0.05)$ on both fertile and non-fertile eggs stored at room and refrigerator temperature. The haugh unit of fertile egg stored in refrigerator is significantly higher $(\mathrm{p}<0.05)$ than all the storage method. There was no significant difference $(p>0.05)$ recorded for shape index.

Figure 1 shows the effect of temperature difference on sensory evaluation of fertile and non-fertile egg. There was no significant difference $(\mathrm{p}>0.05)$ that existed for odour, aroma, taste, texture and overall acceptability for all the treatments. However, there was significant difference $(p<0.05)$ between fertile and non-fertile yolk colour. The yolk colour for fertile eggs stored at ambient temperature and refrigerator temperature are statistically similar $(p>0.05)$. While the yolk colour for non-fertile eggs stored at room temperature was more intense and non-fertile eggs at refrigerator temperature was recorded as the least. 
Egg quality and sensory evaluation as affected by temperature and storage

Table 1: Main effect of temperature difference on fertile and non-fertile egg external and internal characteristics

\begin{tabular}{|c|c|c|c|c|c|}
\hline \multirow[b]{2}{*}{ Parameter } & \multicolumn{2}{|c|}{ Fertile Egg } & \multicolumn{2}{|c|}{ Non-Fertile Egg } & \multirow[b]{2}{*}{ SEM } \\
\hline & $\begin{array}{c}\text { Room } \\
\text { Temperature }\end{array}$ & $\begin{array}{l}\text { Refrigerator } \\
\text { Temperature }\end{array}$ & $\begin{array}{c}\text { Room } \\
\text { Temperature }\end{array}$ & $\begin{array}{l}\text { Refrigerator } \\
\text { Temperature }\end{array}$ & \\
\hline Egg weight (g) & $67.18^{\mathrm{ab}}$ & $68.72^{\mathrm{a}}$ & $65.30^{\mathrm{b}}$ & $69.24^{\mathrm{a}}$ & 0.62 \\
\hline Egg length $(\mathrm{mm})$ & 56.76 & 58.52 & 57.94 & 58.00 & 0.31 \\
\hline Egg Width (mm) & 49.96 & 44.84 & 44.30 & 44.96 & 0.19 \\
\hline Yolk weight (g) & $16.84^{\mathrm{b}}$ & $18.50^{\mathrm{a}}$ & $18.40^{\mathrm{a}}$ & $17.36^{\mathrm{ab}}$ & 0.26 \\
\hline Yolk height (mm) & $15.18^{\mathrm{ab}}$ & $15.90^{\mathrm{a}}$ & $13.82^{\mathrm{c}}$ & $14.68^{\mathrm{bc}}$ & 0.19 \\
\hline Yolk diameter (mm) & $39.96^{\mathrm{bc}}$ & $39.68^{c}$ & $41.40^{\mathrm{a}}$ & $41.16^{\mathrm{ab}}$ & 0.22 \\
\hline yolk colour & 9.92 & 10.02 & 9.78 & 10.00 & 0.07 \\
\hline Yolk ratio & $25.36^{\mathrm{b}}$ & $26.94^{\mathrm{ab}}$ & $28.21^{\mathrm{a}}$ & $25.41^{b}$ & 0.34 \\
\hline Yolk index & $38.23^{\mathrm{ab}}$ & $40.14^{\mathrm{a}}$ & $33.82^{\mathrm{c}}$ & $36.00^{b c}$ & 0.54 \\
\hline Albumen weight (g) & $42.38^{c}$ & $45.92^{b}$ & $42.68^{c}$ & $48.90^{\mathrm{a}}$ & 0.62 \\
\hline Albumen height (mm) & $5.56^{\mathrm{b}}$ & $6.20^{\mathrm{a}}$ & $4.62^{\mathrm{c}}$ & $5.28^{\mathrm{b}}$ & 0.11 \\
\hline Albumen length (mm) & $97.74^{\mathrm{bc}}$ & $93.50^{c}$ & $108.88^{\mathrm{a}}$ & $100.80^{\mathrm{b}}$ & 1.27 \\
\hline Albumen ratio & $63.67^{b}$ & $66.69^{b}$ & $66.33^{b}$ & $71.65^{\mathrm{a}}$ & 0.98 \\
\hline Albumen index & $5.88^{\mathrm{c}}$ & $6.78^{\mathrm{b}}$ & $4.57^{\mathrm{d}}$ & $7.41^{\mathrm{a}}$ & 0.50 \\
\hline Yolk:Albumen & $0.41^{\mathrm{a}}$ & $0.41^{\mathrm{ab}}$ & $0.44^{\mathrm{a}}$ & $0.37^{\mathrm{b}}$ & 0.01 \\
\hline Haugh unit (\%) & $68.89^{\mathrm{b}}$ & $74.57^{\mathrm{a}}$ & $60.06^{\mathrm{d}}$ & $64.55^{\mathrm{c}}$ & 1.05 \\
\hline Egg surface area $\left(\mathrm{mm}^{2}\right)$ & $538.19^{\mathrm{ab}}$ & $550.52^{\mathrm{a}}$ & $523.13^{\mathrm{d}}$ & $554.69^{\mathrm{a}}$ & 5.00 \\
\hline Shape index & 79.41 & 77.16 & 76.79 & 77.97 & 0.51 \\
\hline
\end{tabular}

$\overline{\mathrm{a}, \mathrm{b}, \mathrm{c}, \mathrm{d}}$ means with different superscripts on the same column differ significantly $(\mathrm{P}<0.05)$

Main effect of storage days on fertile and non-fertile egg external and internal characteristics

Table 2 showed the main effect of storage days on fertile and non-fertile egg external and internal characteristics. The egg weight was significantly $(\mathrm{p}<0.05)$ higher at storage day 10 , than all the storage days. The egg length was recorded to be the highest at storage day 10 , while the egg width was recorded the highest at storage day 20 . The yolk weight for storage day 10 was significantly $(p<0.05)$ higher than all the storage days. There was no significant difference $(p>0.05)$ existed between the yolk heights on all the storage days.

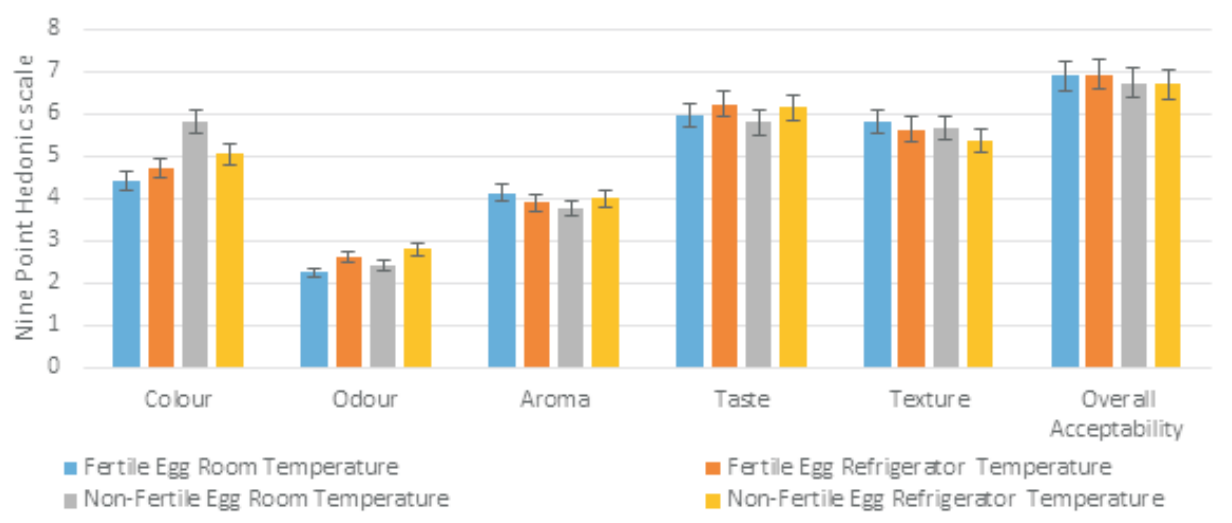

Figure 1: Effect of temperature difference on sensory evaluation of fertile and nonfertile eggs 
The yolk diameter for storage days 5, 10 and 15 were statistically similar $(\mathrm{p}>0.05)$. The yolk colour was significantly $(\mathrm{p}<0.05)$ higher on storage day 15 and lower on day 0 . The yolk ratio has the highest value at storage day 15 and yolk index has the highest at storage day 0 with low values at day 0 and day 20 respectively. There was no significant difference $(p>0.05)$ in the albumen weight at storage days 0 and 5 . Likewise, there was non-significant difference $(p>0.05)$ between the albumen weight at storage days 15 and 20. The albumen heights decreased significantly $(p<0.05)$ as the days of storage increased. However, the albumen height of eggs on storage days 0 was significantly $(\mathrm{p}<0.05)$ higher than all the storage days. The albumen length increases significantly $(\mathrm{p}<0.05)$ as the days of storage increases. The albumen length at storage day 20 was significantly $(\mathrm{p}<0.05)$ higher than all the storage days. There was significant $(\mathrm{p}<0.05)$ difference in the yolk: albumen and egg surface area across the storage days while shape index shows no significant $(\mathrm{p}>0.05)$ difference. The Haugh units decreased significantly $(\mathrm{p}<0.05)$ during the period of storage.

Table 2: Main effect of storage days on fertile and non-fertile egg external and internal characteristics

\begin{tabular}{lcccccc}
\hline & \multicolumn{5}{c}{ Days } & \\
\cline { 2 - 5 } Parameter & 0 & 5 & 10 & 15 & 20 & SEM \\
\hline Egg weight $(\mathrm{g})$ & $62.80^{\mathrm{c}}$ & $64.20^{\mathrm{c}}$ & $79.15^{\mathrm{a}}$ & $62.50^{\mathrm{c}}$ & $69.40^{\mathrm{b}}$ & 0.62 \\
Egg length (mm) & $56.55^{\mathrm{b}}$ & $58.68^{\mathrm{ab}}$ & $59.58^{\mathrm{a}}$ & $57.05^{\mathrm{b}}$ & $57.18^{\mathrm{ab}}$ & 0.31 \\
Egg Width (mm) & $44.20^{\mathrm{ab}}$ & $44.80^{\mathrm{ab}}$ & $45.43^{\mathrm{a}}$ & $43.55^{\mathrm{b}}$ & $45.85^{\mathrm{a}}$ & 0.19 \\
Yolk weight $(\mathrm{g})$ & $15.55^{\mathrm{c}}$ & $16.50^{\mathrm{bc}}$ & $21.38^{\mathrm{a}}$ & $17.45^{\mathrm{b}}$ & $18.00^{\mathrm{b}}$ & 0.25 \\
Yolk height (mm) & 15.08 & 14.8 & 15.2 & 14.65 & 14.75 & 0.19 \\
Yolk diameter (mm) & $37.92^{\mathrm{c}}$ & $40.43^{\mathrm{b}}$ & $40.78^{\mathrm{b}}$ & $40.58^{\mathrm{b}}$ & $43.05^{\mathrm{a}}$ & 0.22 \\
yolk colour & $8.75^{\mathrm{c}}$ & $9.85^{\mathrm{b}}$ & $10.30^{\mathrm{ab}}$ & $10.45^{\mathrm{a}}$ & $10.30^{\mathrm{ab}}$ & 0.07 \\
Yolk ratio & $24.90^{\mathrm{b}}$ & $25.82^{\mathrm{ab}}$ & $27.39^{\mathrm{ab}}$ & $28.07^{\mathrm{a}}$ & $26.26^{\mathrm{ab}}$ & 0.35 \\
Yolk index & $39.88^{\mathrm{a}}$ & $36.76^{\mathrm{b}}$ & $37.37^{\mathrm{ab}}$ & $36.71^{\mathrm{b}}$ & $34.53^{\mathrm{b}}$ & 0.54 \\
Albumen weight $(\mathrm{g})$ & $37.90^{\mathrm{c}}$ & $39.60^{\mathrm{c}}$ & $44.38^{\mathrm{b}}$ & $52.13^{\mathrm{a}}$ & $50.85^{\mathrm{a}}$ & 0.69 \\
Albumen height $(\mathrm{mm})$ & $6.73^{\mathrm{a}}$ & $6.18^{\mathrm{a}}$ & $5.20^{\mathrm{b}}$ & $4.70^{\mathrm{bc}}$ & $4.28^{\mathrm{c}}$ & 0.11 \\
Albumen length (mm) & $83.56^{\mathrm{c}}$ & $98.68^{\mathrm{b}}$ & $98.50^{\mathrm{b}}$ & $110.95^{\mathrm{a}}$ & $109.50^{\mathrm{a}}$ & 1.28 \\
Albumen ratio & $60.49^{\mathrm{cd}}$ & $61.63^{\mathrm{c}}$ & $56.01^{\mathrm{d}}$ & $83.55^{\mathrm{a}}$ & $74.07^{\mathrm{b}}$ & 0.98 \\
Albumen index & $8.19^{\mathrm{ab}}$ & $8.71^{\mathrm{a}}$ & $5.34^{\mathrm{abc}}$ & $4.54^{\mathrm{bc}}$ & $4.03^{\mathrm{c}}$ & 0.54 \\
Yolk:Albumen & $0.41^{\mathrm{b}}$ & $0.42^{\mathrm{b}}$ & $0.49 \mathrm{a}$ & $0.35^{\mathrm{c}}$ & $0.36^{\mathrm{c}}$ & 0.01 \\
Haugh unit $(\%)$ & $80.30^{\mathrm{a}}$ & $75.56^{\mathrm{a}}$ & $61.36^{\mathrm{b}}$ & $62.68^{\mathrm{b}}$ & $55.15^{\mathrm{c}}$ & 1.05 \\
Egg surface area (mm2) & $503.01^{\mathrm{c}}$ & $514.31^{\mathrm{c}}$ & $634.08^{\mathrm{a}}$ & $500.69^{\mathrm{c}}$ & $555.97^{\mathrm{b}}$ & 5.00 \\
Shape index & 78.25 & 76.67 & 76.9 & 77.09 & 80.26 & 1.15 \\
\hline
\end{tabular}

a, b, c, d means with different superscripts on the same column differ significantly $(\mathrm{P}<0.05)$

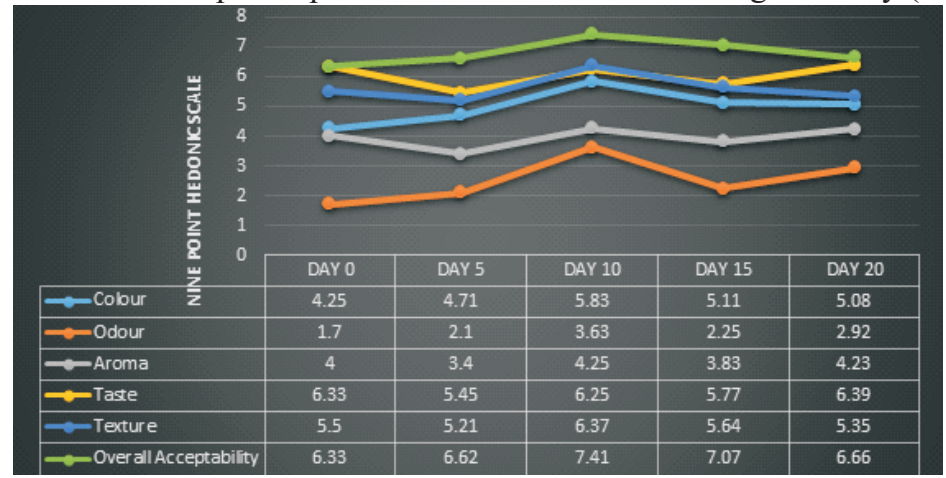

Figure 2: Effect of storage days on sensory evaluation of fertile and non-fertile eggs 


\section{Discussion}

Results from the study shows that, the egg weight, yolk height, albumen height, albumen weight, and the haugh unit decreases as the duration of storage increases. However, the yolk weight increases with storage days. Egg weight loss increases when storage duration increases, and the highest weight losses were recorded at 10 days of storage in both temperatures (room and refrigeration). Weight loss occurs due to loss of water from the egg content through the shell by evaporation. These results are not supported by (Altan et al., 1998; Fasenko et al., 2001; Tilki and Inal 2004; Hassan et al., 2005; Reijrink et al., 2010). GonzalezRedondo (2010) and Also bayel and Albadry (2011), who reported that with increase in the length of storage days, egg weight losses increase. Likewise, loss of egg weight depends on the temperatures. As a result, eggs stored at refrigerator temperature showed significantly $(\mathrm{p}<0.05)$ lower weight loss than room temperature. This may be due to the less loss of solvents (water and other gaseous products) from egg contents than those in room temperature. These results are in agreement with (Shanawa, 1994., Samli et al., 2005; Hasan et al., 2009) who noticed a decrease in egg weight within 10 days of storage at $29^{\circ} \mathrm{C}$.

A yolk weight showed significant $(p<0.05)$ changes during storage, and increased linearly with storage time, which might be due to the diffusion of water from the albumen to the yolk. These results agree with (Haugh, 1937; Barbosa et al., 2004) On the other hand, when the storage temperature was higher, the rate of increase in yolk weight was significantly $(\mathrm{p}<0.05)$ higher than in refrigeration $\left(4^{\circ} \mathrm{C}\right)$. These results are supported by (Davis \& Stephenson, 1991; Morais et al., 1997; Leandro et al., 2005) who reported that the most important factors that affect egg quality during storage are temperature and relative humidity.

\section{Conclusion}

The study showed that fertile eggs can be stored in refrigerator at $10^{\circ} \mathrm{C}$ for 10 days without adverse effect on egg and eating qualities.

\section{References}

Alsobayel, A. A. and Albadry, M. A. 2011. Effect of storage period and strain of layer on internal and external quality characteristics of eggs marketed in Riyadh area. Journal of the Saudi Society of Agricultural Sciences 10:41-45.

Altan, O., Dguz, L. and Akbas, Y. 1998. Effect of selection for high body weight and age of hen on egg characteristics in Japanese quail (Coturnixcoturnix japonica). Turkey Journal of Veterinary and Animal Science 92 Journal of Food, Agriculture \& Environment, Vol.12 (3\&4), July-October 2014 22:67-473.

Barbosa, N. A. A., Freitas, E. R., Sakomura, N. K. and Wada, M. T. 2004. Efeito da temperatura e do tempo de armazenamento na qualidade interna de ovos de poedeiras comerciais. Brazilian Journal Poultry Science 60(6):6065.

Bell, D. 1996. Effects of temperature and storage time on egg weight loss. Poultry International 35(14):56-64.

Davis, B. H. and Stephenson, H. P. 1991. Egg quality under tropical conditions in north Queensland. Food Australia 43:496-499.

Food and Health Organization, FAO Corporate Document Repository (FAO- CDR) 2003. Egg marketing- Marketing Quality 
Nwamo, Oshibanjo, Sati, Emennaa, Mbuka, Njam, Bature, Ejidare, Gyang, Adeniyi, Mohammed, Luka J. Agwom and Ene

Eggs. Chapter Two. Agriculture and consumer protection. Available a

http://www.fao.org/docrep/005/y $4628 \mathrm{e} / \mathrm{y} 4628 \mathrm{e} 04 . \mathrm{html}$.

Retrieved on 20/09/19.

Fasenko, G. M., Robinson, F. E., Whelan, A. I., Kremeniuk, K. M. and Walker, J. A. 2001. Prestorage incubation of long-term stored broiler eggs: 1. Effect on hat chability. Poultry Science80(10):1406-1411.

Fasina, D.E., Oke, M.O., and Oke, D.B. 2012. Influence of different storage conditions on cholesterol content of domestic fowl egg. ASANNIAS proceedings.

George Meltegan 2015. The World's Healthiest Foods- Eggs: Pasture raised. Available at http://www.whfoods.com/genpage. $\mathrm{p} \mathrm{h} \mathrm{p} \mathrm{?} \mathrm{t} \mathrm{n} \mathrm{a} \mathrm{m} \mathrm{e}=\mathrm{f}$ o o d spice $\$$ dbid $=92 . h t m l$. Retrieved on 20/09/19.

Gonzalez-Redondo, P. 2010. Effect of long-term storage on the hatchability of red-legged partridge (Alectoris rufa) eggs. Poultry Science89(2):379-383.

Haruna, U., Daneji, M. I. and Idi, S. 2007. Comparative Economic Analysis of Adopters and Non-adopters in Bauchi LGA, Bauchi State. Proceedings of the 8th Annual conference Nigerian Society for Animal Production, AESON, pp: 55-62.

Hasan, A. and Aylin, A. O. 2009. Effect of Storage time, temperature and Hen age on egg quality in free-range layer Hens. Journal of Animal and Veterinary Advances. 8 (10): 1953 $-1958$.

Hasan, A. and Okur, A. A. 2009. Effect of storage time, temperature and hen age on egg quality in free-range layer hen. Journal of Animal and Veterinary Advances8(10):19531958.

Hassan, S. M., Siam, A. A., Mady, M. E. and Cartwright, A. L. 2005. Egg storage period and weight effects on hatchability of ostrich (Struthiocamelus) eggs. Poultry Science84(12):1908-1912.

Haugh, R. R. 1937. The Haugh unit for measuring egg quality. United States Egg and Poultry Magazine 43:552-555, 572-573.

Joseph, J. K. and Ogundele, O. G. 1996. Shelf life of hen's egg as influenced by coating with shear butter fat, palm kernel oil and film packaging. Nigerian Journal of Pure and Applied Science 11:398-404

Kristy, S. W. 2011. Quality and Sensory attributes of shell eggs sanitized with a combination of hydrogen peroxide and ultraviolet light. A Thesis- Texas A \$M University.

Leandro, N. S. M., Deus, H. A. B., Stringhini, J. H., Café, M. B., Andrade, M. A. and Carvalho, F. B. 2005. Aspectos de qualidade interna e externa de ovos comercializados em diferentes estabelecimentos na região de Goiânia. Ciência Animal Brasileira 6(2):71-78.

Mohammed, H. T. 2011. Impact of Storage Period and Quality on Composition of Table egg. Advances in Environmental Biology 5(5): 856861.

Morais, C. F. A., Campos, E. J. and Silva, T. J. P. 1997. Qualidade interna de ovos comercializados em diferentes supermercados na cidade de Uberlândia. Arquivo Brasileiro de Medicina Veterinária e Zootecnia 49:365-373.

Obi. O. and Igbokwe, A.J. 2009. Microbial Analyses of freshly laid 
and stored domestic poultry eggs in selected poultry farms in Umuahia, Abia. Nigeria. Research Journal of Biological Sciences. 4(12): 12971303.

Okeudo, N. J., Ezetoha, U., Akomas, C. and Akanno, E. C. 2005. Egg quality of Gallus Domesticus under domestic storage in Nigeria. Animal Resesrch International 2(2): 391-321.

Raji, A. O., Aliyo, J., Igwubuike, J. U. and Chiroma, S. 2009. Effect of Storage Methods and time on Egg Quality storage traits of laying hens in hot dry climate. Asian Research Publishing Network. Journal of Agricultural and Biological Science 4:4.

Reijrink, D., Berghmans, R., Kemp Meijerof, B. and Van den Brand, H. 2010. Influence of egg storage time and pre-incubation warming profile on embryonic development, hatchability, and chick quality. Poultry Science89(6):1225-1238.

Samli, H. E., Agna, A. and Senkoylu, N. 2005. Effects of storage time and temperature on egg quality in old laying hens. Journal of Applied Poultry Research14:548-533.

SAS. 2010. SAS/STAT User's Guide: Version 9.2. SAS Institute Inc., Cary. NC., USA; 2010.

Scotts, T. A. and Silversides, F. G. 2000. The Effect of Storage and Strains of Hen on Egg Quality. Poultry Sciences and Technology 79: 17251729.
Shanawa, M. M. 1994. Quail Production Systems. A review. Food and Agriculture Organization of the United Nations, Rome, 145 p.

Stadelman, W. J. 1995. Quality identification shell egg. In $\mathrm{S} \mathrm{t}$ a $\mathrm{d}$ e $\mathrm{l}$ a $\mathrm{n}$, W. J. and Cotterill, O. J. (eds). Egg Science and Technology. 4th edn. The Haworth Press, Inc., New York, London, pp. 39-66.

Stadelman, W. J and Coterill, O. J. 1986. The preservation of quality of Shell eggs. In: Stadelmann and Coterill O.J. (eds). Egg Science and Technology. Avi Publishing com., Inc, WestPort, Connecticut, USA.United States of Department of Agriculture- Agriculture Marketing Service, USDA-AMS (2000): Egg grading manual. Agricultural Marketing Division. Agricultural Handbook NO.75, U.S.Department of Washington D.C.

Tilki, M. and Inal, S. 2004. Quality traits of goose eggs. 1. Effects of goose age and storage time of eggs. Arch. für Geflügelk. 68:82-186.

Zeidler, G. 2002. Shell quality and preservation. In Bell, D. D. \& $\mathrm{W}$ e a $\mathrm{v}$ e $\mathrm{r}$, W. D. Jr. (eds). Commercial Chicken Meat and Egg Production. $5 \mathrm{t} \mathrm{h} \quad \mathrm{r}$ e $\mathrm{V}$. edn. Kluwer Academic Publishers, Norwell, pp. 1199-1217.

Received: $12^{\text {th }}$ November, 2020 Accepted: $15^{\text {th }}$ February, 2021 